\title{
SUBSTRATES AND CONTAINER VOLUMES IN THE PRODUCTION OF MANGABEIRA SEEDLINGS (Hancornia speciosa Gomes)
}

\author{
Aline Borges Vilela Silva ${ }^{1}$, Ana Claudia Costa ${ }^{2}$ Erika Katianne Costa Pinho ${ }^{1}$ e Rodrigo de Goes Esperon Reis ${ }^{2}$ \\ 'Engenheira Agrônoma, Universidade do Estado de Mato Grosso (UNEMAT), Campus de Nova Xavantina, Av. Prof. Dr. Renato Figueiro \\ Varella, s/nº, Nova Xavantina-MT, Cx Postal 08 - CEP 78.690-000. \\ ${ }^{2}$ Professor da Universidade do Estado de Mato Grosso (UNEMAT), Campus de Nova Xavantina, Av. Prof. Dr. Renato Figueiro Varella, s/ \\ $\mathrm{n}^{0}$, Nova Xavantina-MT, Cx Postal 08 - CEP 78.690-000. \\ *Autora para correspondência: Ana Claudia Costa, anaclaudiacosta@unemat.br
}

\begin{abstract}
Mangabeira (Hancornia speciosa Gomes), a fruit tree native to the Brazilian Cerrado, has great potential for commercial cultivation due to the quality of fruits, which can be consumed fresh or processed. However, it is necessary to expand research in the area of propagation of this fruit tree. The aim of this study was to evaluate different substrates and container volumes in the production of mangabeira seedlings, $H$. speciose, in Nova Xavantina-MT. The experiment was carried out at the nursery of the Mato Grosso State University (UNEMAT), Campus of Nova Xavantina in a randomized block design, in a $2 \times 4$ factorial scheme, with two container volumes $\left(0.9\right.$ e $\left.1.8 \mathrm{dm}^{3}\right)$ and four substrates (soil; soil + sand; soil + sand + bovine manure; and commercial substrate), totalizing eight treatments with four replicates and plots composed of 10 plants each. The greatest growth of mangabeira seedlings was observed using soil or soil + sand + bovine manure and $1.8 \mathrm{dm}^{3}$ container.
\end{abstract}

KEYWORDS: Apocynaceae, cerrado fruit, propagation, nursery

\section{SUBSTRATOS E VOLUMES DE RECIPIENTE NA PRODUÇÃO DE MUDAS DE MANGABEIRA (Hancornia speciosa Gomes)}

RESUMO: A mangabeira (Hancornia speciosa Gomes), frutífera nativa do Cerrado, possui grande potencial para cultivo comercial devido às qualidades de seu fruto que pode ser consumido ao natural ou processado. No entanto, faz-se necessária a ampliação de pesquisas na área de propagação dessa frutífera. 0 presente trabalho teve como objetivo avaliar diferentes substratos e volumes de recipiente na produção de mudas de mangabeira, H. speciosa, em Nova Xavantina-MT. O experimento foi realizado no viveiro da Universidade do Estado de Mato Grosso (UNEMAT), Campus de Nova Xavantina. O delineamento experimental foi em blocos casualizados, em esquema fatorial $2 \times 4$, sendo dois volumes de recipiente $\left(0,9\right.$ e $\left.1,8 \mathrm{dm}^{3}\right)$ e quatro substratos (solo; solo + areia; solo + areia + esterco bovino e substrato comercial), totalizando oito tratamentos com quatro repetições e parcela composta por 10 plantas. Maior crescimento das mudas de mangabeira ocorre quando se utiliza solo ou solo + areia + esterco bovino no recipiente de $1,8 \mathrm{dm}^{3}$.

PALAVRAS-CHAVE: Apocynaceae, fruta do cerrado, propagação, viveiro

\section{INTRODUCTION}

Considered a heritage of renewable natural resources with potential to be commercially exploited, the Brazilian Cerrado is the center of origin of several fruit trees, whose varied fruits provide a very promising market niche (Morzelle et al., 2015). Mangabeira (Hancornia speciosa Gomes) belonging to the Apocynaceae family, is among native fruits of the Brazilian Cerrado, with fruits highly appreciated by consumers (Oliveira et al., 2018), which can be consumed both fresh and processed in the form of pulps, jellies, ice cream, juices, sweets, cakes, cookies and liquors.

In addition to fruits, other important by-products with pharmacological potential can be extracted from this plant. For example, studies have shown that $H$. speciosa leaves have bioactive compounds that effectively control blood pressure (Silva et al., 2011) and diabetes (Pereira et al., 2015); and the latex of this species has anti-inflammatory action (Marinho et 
al., 2011). Despite the great food and pharmaceutical potential, the species is at risk of disappearing, mainly from Cerrado regions, due to the expansion of agricultural frontiers and intense agriculture and cattle raising activity (Sá et al., 2011).

The plant has average height of 4-7 meters, with capacity to reach up to 15 meters, has tortuous and rough trunk and with cracked bark. Fruits are of berry type with size, shape and colors varying according to the region of occurrence, being usually ellipsoidal or rounded, yellowish or greenish and of soft texture, with size ranging from 2.5 to $6.0 \mathrm{~cm}$ (Pinheiro et al., 2018).

Extractivism is still the main form of mangaba exploitation. During part of the year, countless families have an important occupation and source of income in mangaba harvesting and marketing, which fruit has high pulp yield, around 94\% (Silva Júnior; Ledo, 2006). The implementation of commercial mangabeira orchards is important because it allows for the proper crop management, guaranteeing high yields and fruit quality. For the successful implementation of a mangabeira orchard, it is necessary to obtain healthy seedlings, produced in screened nurseries, which will favor the health of plants in the field and the production of quality fruits. The spread of mangabeira can be performed by seeds or by grafting. Due to the high degree of recalcitrance, mangabeira seeds should be sown the next day or at most two to three days after extraction (Pereira et al., 2016).

The quality of seedling is due, among several factors, to the type of substrate used, as it directly interferes with germination, root growth, water retention, aeration, among others (Paiva Sobrinho, 2010). Substrates are pure materials or a mixture of various materials and must be sources of organic or inorganic nutrients that meet the needs of each species (Arrua et al., 2016).

The substrate interferes with the quality of propagated plants due to the variation of their physical, chemical and biological properties (Costa et al., 2018; Morais et al., 2017). In addition to substrate, the appropriate choice of the type of container to be used is also important, considering its durability, area occupied in the nursery, easy movement and characteristics for the formation of quality seedlings.

The aim of this study was to evaluate different substrates and container volumes in the production of mangabeira, $H$. speciose, seedlings in Nova Xavantina-MT.

\section{MATERIAL AND METHODS}

The experiment was carried out from November 2017 to March 2018 at the nursery of the Mato Grosso State University (UNEMAT), Campus of Nova Xavantina-MT, located at $14^{\circ} 40^{\prime} 00^{\prime \prime} \mathrm{S}$ and $52^{\circ} 20^{\prime} 45^{\prime \prime} \mathrm{W}$ and $271 \mathrm{~m}$ a.s.I. The climate of the region is $A w$, according to the Köppen climate classification, hot and sub-humid tropical with dry period, average annual temperature of $25.1^{\circ} \mathrm{C}$ and average precipitation of 1,498 mm (Climate, 2018).

The soil used in the experiment was collected in the experimental area of the Mato Grosso State University, Campus of Nova Xavantina-MT, at the $0-20 \mathrm{~cm}$ layer. The results of the soil physicochemical analysis are described in Table 1.

Table 1. Chemical and physical analysis of soil used as substrate for the production of mangabeira seedlings in different container volumes and substrate types.

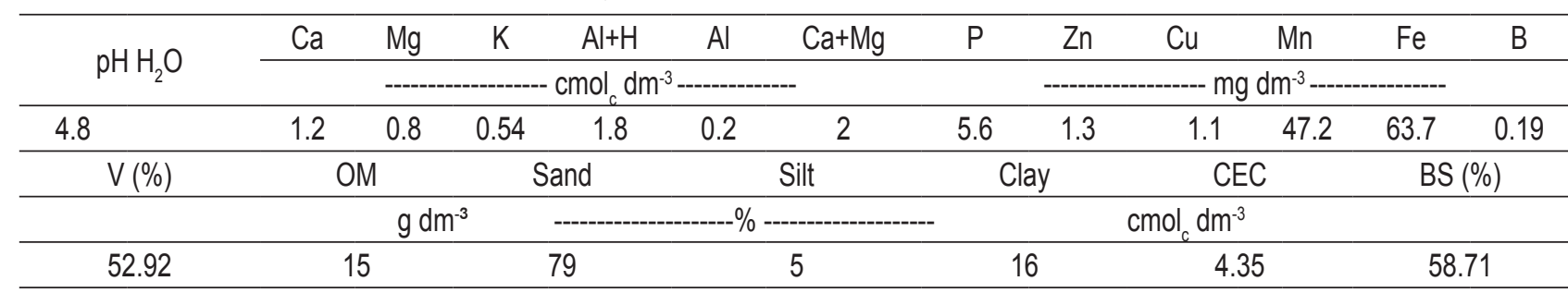

Bovine manure was obtained from farms in the region of Piranhas-GO and tanned for 60 days, collecting a sample for analysis of the chemical composition of this material (Table 2).

Ripe mangabeira fruits were collected from three healthy plants with approximately ten years of age at Bananal Farm, located in the municipality of PiranhasGO, in November 2017. According to the Köppen and Geiger classification, the climate of the region where mother plants are located is of Aw type with average temperature of $25.5^{\circ} \mathrm{C}$ and average annual rainfall of $1598 \mathrm{~mm}$ (Climate, 2018). 
Table 2. Chemical analysis of tanned bovine manure used in the substrate composition in the production of mangabeira seedlings using different container volumes and substrate types.

\begin{tabular}{cccc}
\hline \multirow{2}{*}{$\mathrm{pH} \mathrm{H}_{2} \mathrm{O}$} & $\mathrm{N}$ & $\mathrm{P}_{2} \mathrm{O}_{5}$ & $\mathrm{~K}_{2} \mathrm{O}$ \\
\cline { 2 - 4 } & $\mathrm{g} \mathrm{kg}^{-1}$ & $\mathrm{~g} \mathrm{~kg}^{-1}$ & $\mathrm{~g} \mathrm{~kg}^{-1}$ \\
\hline 2.5 & 16.5 & 20.0 & 23.5 \\
\hline
\end{tabular}

Fruits were manually pulped and seeds were washed under running water until complete removal of mucilage to eliminate possible germination inhibiting substances, being then dipped in $2.5 \%$ sodium hypochlorite solution and stirred for 5 minutes for disinfestation. Subsequently, seeds were placed to dry in a closed environment at temperature of $22^{\circ}$ $C$ to avoid loss of moisture and stored in plastic bags according to Queiroz and Blanchetti (2001) for eight days until sowing.

Sowing was manually carried out in polyethylene plastic bags with dimensions of $12 \times 20$ $\mathrm{cm}\left(0.9 \mathrm{dm}^{3}\right)$ and $15 \times 25 \mathrm{~cm}\left(1.8 \mathrm{dm}^{3}\right)$, sowing four seeds per container. Substrates used were soil, soil + sand + cattle manure (1: 1: 1), soil + sand (1:1) and commercial substrate (Tecnomax $\AA)$.

After filling, plastic bags were placed on benches at the UNEMAT Seedling Production Nursery with $50 \%$ shading screen. Germinated seeds were counted at 20 days after sowing, considering as normal seedlings those with all their essential structures well developed. Thus, the germination percentage was calculated using the formula $G=(N$ (A) $\times 100$, where: $\mathrm{N}=$ number of germinated seeds; $A=$ number of seeds per plot $(A=40)$ (Soares et al., 2014). After 20 days of sowing, thinning was carried out, leaving only the most vigorous plant per container. Irrigation was daily performed with watering can, distributing water evenly over seedlings. Weed control was manually performed.

After 120 days of sowing, the following agronomic variables were evaluated: plant height $(\mathrm{cm})$, measured with the aid of millimeter ruler; stem diameter $(\mathrm{mm})$, measured with digital caliper $( \pm 0.01 \mathrm{~mm}) 2$ $\mathrm{cm}$ above the seedling stem; number of leaves; fresh and dry shoot and root mass; and the Dickson Quality Score, applying the formula:

$$
\text { IQD }=\frac{\text { MST }}{\frac{\mathbf{H}}{D C}+\frac{M S P A}{M S R}}
$$

Where:
MST: Total dry mass (g) (MSPA + MSR); H: Height (cm); DC: stem diameter (mm); MSPA: Dry shoot mass (g); MSR: Dry root mass $(\mathrm{g})$.

At the end of the experiment, seedlings were removed from bags, washed in running water and roots were separated from shoots. After this procedure, shoots and the root system of plants in each plot were placed in paper bags and weighed separately on analytical scale $( \pm 0.01 \mathrm{~g})$ to determine the fresh mass. Subsequently, the material was taken to the oven with forced air circulation at $65{ }^{\circ} \mathrm{C}$ until reaching constant weight, and then weighed to determine the dry mass of plant parts.

The experiment had randomized blocks design (RBD) in 2 (container volumes) $\times 4$ (substrates) factorial scheme with four blocks, eight plots per block and each plot consisting of 10 plants.

Data were submitted to analysis of variance and the means of substrates were compared by the Tukey test at $5 \%$ probability. The comparison between container volumes was performed by the $F$ test, and statistical analyses were performed using the Svar $₫$ software.

\section{RESULTS AND DISCUSSION}

According to the analysis of variance, there was significant interaction between factors evaluated (substrate $x$ container volume) only for fresh shoot and fresh root mass and dry shoot mass. There was an effect of substrates and container volumes when evaluated separately for all characteristics, except for plant height, for which there was an effect only of substrates used. There was no effect of treatments evaluated for the germination percentage of mangabeira seeds (Table 3 ), with average germination of $82.52 \%$. Soares et al. (2014) found maximum germination percentage $(79 \%)$ when mangabeira seeds were submitted to $33 \mathrm{~h}$ of drying. Nunes (2018) verified $81 \%$ germination when manual processing of mangaba trees was carried out, corroborating results obtained in this work. 
Table 3. Germination percentage of mangabeira seeds in different substrates and container volumes.

\begin{tabular}{cc}
\hline Treatments & \% germination \\
\hline T1 & 85.62 \\
T2 & 85.00 \\
T3 & 83.12 \\
T4 & 84.37 \\
T5 & 86.87 \\
T6 & 86.87 \\
T7 & 82.50 \\
T8 & 65.87 \\
\hline Mean & 82.53 \\
\hline
\end{tabular}

$\mathrm{T} 1$ - soil in $0.9 \mathrm{dm}^{3}$ container; $T 2$ - soil + sand in $0.9 \mathrm{dm}^{3}$ container; T3- soil + sand + bovine manure in $0.9 \mathrm{dm}^{3}$ container; T4- commercial substrate in $0.9 \mathrm{dm}^{3}$ container; T5 - soil in $1.8 \mathrm{dm}^{3}$ container; T6- soil + sand in $1.8 \mathrm{dm}^{3}$ container; T7- soil + sand + bovine manure in 1.8 $\mathrm{dm}^{3}$ container; $\mathrm{T} 8$ - commercial substrate in $1.8 \mathrm{dm}^{3}$ container.

Substrates containing soil and soil + sand + leaves (14.42), followed by treatment composed only bovine manure provided greater height $(15.80 \mathrm{~cm}$ and of soil (13.20) (Table 4). Substrates formulated with $15.69 \mathrm{~cm})$ and stem diameter $(3.10 \mathrm{~mm}$ and $3.06 \mathrm{~mm})$ soil + sand and commercial substrate did not favor the of mangabeira seedlings. Substrate composed of soil analyzed parameters.

+ sand + bovine manure provided greater number of

Table 4. Plant height $(H)$, stem diameter (D) and number of leaves (NF) of mangabeira seedlings Hancornia speciosa Gomes produced on different substrates.

\begin{tabular}{cccc}
\hline Substrate & $\mathrm{H}(\mathrm{cm})$ & $\mathrm{D}(\mathrm{mm})$ & $\mathrm{NF}$ \\
\hline Soil & $15.80 \mathrm{a}$ & $3.10 \mathrm{a}$ & $13.20 \mathrm{~b}$ \\
Soil + A & $13.01 \mathrm{~b}$ & $2.69 \mathrm{~b}$ & $11.97 \mathrm{c}$ \\
Soil + A + EB & $15.69 \mathrm{a}$ & $3.06 \mathrm{a}$ & $14.42 \mathrm{a}$ \\
SC & $11.83 \mathrm{~b}$ & $2.57 \mathrm{~b}$ & $11.40 \mathrm{c}$ \\
\hline DMS & 1.53 & 0.18 & 1.19 \\
\hline
\end{tabular}

Means followed by the same letter in column do not differ by the Tukey's test at $5 \%$ probability, $A=$ sand, $E B=$ cattle manure, $\mathrm{SC}=$ commercial substrate.

Substrates formulated with organic matter generally present greater fertility by favoring physical, chemical and biological soil attributes and seedling growth. In general, plants native to the Brazilian Cerrado have tolerance to soil conditions that limit the growth of other species due to the presence of acidity-tolerant mechanisms. It should be highlighted that the soil used in this study may have favored the growth parameters evaluated due to the high fertility verified by the high potassium content $\left(0.54 \mathrm{cmol}_{\mathrm{c}} \mathrm{dm}^{-3}\right)$ and adequate base saturation $(58.71 \%)$ (Table 1$)$.

Table 5 shows that the seedlings produced in larger container $\left(1.8 \mathrm{dm}^{3}\right)$ provided larger stem diameter $(2.79 \mathrm{~mm})$ and greater number of leaves (13.25). Container volume did not influence plant height.

Table 5. Plant height (H), stem diameter (D) and number of leaves (NF) of mangaba seedlings Hancornia speciosa Gomes produced in different container volumes.

\begin{tabular}{cccc}
\hline Container $\left(\mathrm{dm}^{3}\right)$ & $\mathrm{H}(\mathrm{cm})$ & $\mathrm{D}(\mathrm{mm})$ & $\mathrm{NF}$ \\
\hline 0.9 & $14.19 \mathrm{a}$ & $2.79 \mathrm{~b}$ & $12.24 \mathrm{~b}$ \\
1.8 & $13.98 \mathrm{a}$ & $2.92 \mathrm{a}$ & $13.25 \mathrm{a}$ \\
\hline DMS & 0.80 & 0.09 & 0.63 \\
\hline
\end{tabular}

Means followed by the same letter in column do not differ by the $\mathrm{F}$ test at $5 \%$ probability. 
Container size directly influences the volume of substrate available for root and shoot growth (Zaccheu et al., 2013). The larger the container, the higher the substrate volume and, consequently, the greater availability of nutrients and especially the greater volume and water retention, which can result in greater seedling growth.

Queiroz and Melém Júnior (2001) found that the use of larger containers directly influences the final seedling cost, as it requires greater amount of substrate, labor during transport to benches and space in the nursery; on the other hand, smaller containers can cause stress to seedlings, folding of the root system (Neves et al., 2005) and increased allocation of photoassimilates to roots (Samôr et al., 2002). In general, the container size must be chosen in order to provide the greatest possible volume of substrate to roots, but with less weight to facilitate transport. In addition, it should be considered that Cerrado species have naturally long, tuberous and thick roots, which can be four to ten times larger than shoots. In this case, larger containers can be more suitable for these plants, being more advantageous during their initial growth phase (EMBRAPA, 2016).

In experiments with seedling production, it is important to evaluate features such as plant height and stem diameter during growth, since for successful establishment of field crops, seedlings must be of adequate size and thickness so that they are not easily damaged by pests, diseases or climatic factors (Cargnelutti Filho et al., 2012).

Greater fresh shoot mass was observed when soil or soil + sand + bovine manure substrate was used for both containers (Table 6).

Table 6. Fresh shoot mass (MFPA) and fresh root mass (MFR) and dry shoot mass (MSPA) of mangabeira seedlings Hancornia speciosa Gomes produced on different substrates and container volumes.

\begin{tabular}{|c|c|c|c|c|c|c|}
\hline Substrate & $\begin{array}{l}\text { Container } \\
0.9 \mathrm{dm}^{3}\end{array}$ & $\begin{array}{c}\text { Container } \\
1.8 \mathrm{dm}^{3}\end{array}$ & $\begin{array}{l}\text { Container } \\
0.9 \mathrm{dm}^{3}\end{array}$ & $\begin{array}{c}\text { Container } \\
1,8 \mathrm{dm}^{3}\end{array}$ & $\begin{array}{c}\text { Container } \\
0,9 \mathrm{dm}^{3}\end{array}$ & $\begin{array}{c}\text { Container } \\
1,8 \mathrm{dm}^{3}\end{array}$ \\
\hline & \multicolumn{2}{|c|}{ MFPA (g plant ${ }^{-1}$ ) } & \multicolumn{2}{|c|}{ MFR (g plant $\left.{ }^{-1}\right)$} & \multicolumn{2}{|c|}{ MSPA (g plant ${ }^{-1}$ ) } \\
\hline Soil & $2.57 \mathrm{aB}$ & $3.59 \mathrm{aA}$ & $1.65 \mathrm{abB}$ & $2.08 \mathrm{aA}$ & $0.80 \mathrm{aB}$ & $1.12 \mathrm{aA}$ \\
\hline Soil + sand & $1.84 \mathrm{bB}$ & $2.59 \mathrm{bA}$ & $1.30 \mathrm{bB}$ & $1.79 \mathrm{abA}$ & $0.53 \mathrm{bB}$ & $0.80 \mathrm{cA}$ \\
\hline$S+A+E B$ & $2.89 \mathrm{aB}$ & $3.28 \mathrm{aA}$ & $1.19 \mathrm{bA}$ & $1.48 \mathrm{bA}$ & $0.83 \mathrm{aB}$ & $0.97 \mathrm{bA}$ \\
\hline \multirow[t]{2}{*}{ SC } & $2.03 \mathrm{bA}$ & $1.87 \mathrm{cA}$ & $2.05 \mathrm{aA}$ & $1.71 \mathrm{abA}$ & $0.59 \mathrm{bA}$ & $0.53 \mathrm{dA}$ \\
\hline & \multicolumn{2}{|c|}{ DMS1 $=0.51$} & \multicolumn{2}{|c|}{ DMS1 $=0.57$} & \multicolumn{2}{|c|}{ DMS1 $=0.13$} \\
\hline
\end{tabular}

Means followed by the same lowercase letter in column and uppercase in row do not differ by the Tukey's test at $5 \%$ probability. DMS1 = minimum significant difference between substrates. DMS2 = minimum significant difference between containers. $E B=$ cattle manure. $S C=$ Commercial substrate. $S+A+E B=$ soil + sand + bovine manure .

Regarding fresh root mass, it was found that commercial substrate and soil provided higher averages in container with the lowest volume $\left(0.9 \mathrm{dm}^{3}\right)$, while in containers with higher volume, greater mass was observed using soil, soil + sand and commercial substrate. Rodrigues et al. (2010) suggest that the use of tanned bovine manure in the formulation of substrates for seedlings may eventually not favor root growth of some species due to the presence of substances that can cause toxic effect to roots. Commercial substrates have good physical characteristics (porosity, aeration, water holding capacity and plasticity), which can favor root growth.
Larger volume containers $\left(1.8 \mathrm{dm}^{-3}\right)$ provided greater dry shoot mass in comparison to smaller containers for almost all substrates used, except for commercial substrate, for which no difference between container sizes was observed. In larger containers, substrate composed of soil had dry shoot mass production significantly superior to the other substrates.

Table 7 shows that soil, soil + sand and commercial substrates provided greater dry root mass and Dickson's Quality Index, a seedling quality indicator that considers important parameters for quality evaluation such as acquired biomass; therefore, higher $D Q I$ values indicate greater vigor and possibly better performance in the field. 
Table 7. Dry root mass (MSR) and Dickson's Quality Index (DQI) of mangabeira seedlings Hancornia speciosa Gomes produced on different substrates.

\begin{tabular}{ccc}
\hline Substrate & MSR $(\mathrm{g})$ & DQI \\
\hline Soil & $0.44 \mathrm{a}$ & $0.19 \mathrm{a}$ \\
Soil + sand & $0.39 \mathrm{a}$ & $0.16 \mathrm{ab}$ \\
Soil + sand + EB & $0.28 \mathrm{~b}$ & $0.14 \mathrm{~b}$ \\
Commercial substrate & $0.42 \mathrm{a}$ & $0.16 \mathrm{ab}$ \\
\hline DMS & 0.11 & 0.03
\end{tabular}

Means followed by the same letter in column do not differ by the Tukey's test at $5 \%$ probability. EB $=$ bovine manure.

This fact may indicate that the species, for being native to poor soils, does not always respond to increased organic matter in the substrate, since, according to Melo et al. (1998), some Cerrado species from low-fertility soils do not have good performance regarding the increased substrate fertility and may even be detrimental to seedling development. Arrua et al. (2016) reported that the formation of mangabeira seedlings on substrate containing $30 \%$ or more of bovine manure in a mixture with other materials used (soil, fine sand, medium vermiculite and extra-fine vermiculite) is not recommended. Higher amounts of bovine manure on the substrate provided lower emergence percentage, growth and quality of mangabeira seedlings (Arrua et al., 2016), a fact also verified by Oliveira et al. (2014) in the production of barueiro seedlings and higher proportion of organic compounds harmed the growth of tamarind seedlings (Costa et al., 2012).
Treatments containing soil + sand + bovine manure possibly did not result in higher quality of mangabeira seedlings because the Dickson Quality Index considers dry root mass in its formula, which, in the case of these treatments, had the lowest average $(0.28 \mathrm{~g})$ (Table 7$)$, influencing the indicator used to measure quality (DQI). It is likely that some substances present in the manure used have impaired root growth.

The use of soil as substrate is a low-cost alternative; on the other hand, its use can bring losses due to the possibility of contamination and often low fertility. Commercial substrate, despite the high cost, is a material free of pathogens and with physical and chemical qualities that favor seedling production.

Table 8 shows that larger volume containers provided greater dry root mass and Dickson's Quality Index.

Table 8. Dry root mass (MSR) and Dickson's Quality Index of mangabeira seedlings Hancornia speciosa Gomes produced in different container volumes.

\begin{tabular}{ccc}
\hline Container $\left(\mathrm{dm}^{3}\right)$ & MSR $(\mathrm{g})$ & DQI \\
\hline 0.9 & $0.34 \mathrm{~b}$ & $0.14 \mathrm{~b}$ \\
1.8 & $0.42 \mathrm{a}$ & $0.18 \mathrm{a}$ \\
\hline DMS & 0.05 & 0.01 \\
\hline
\end{tabular}

Means followed by the same letter in column do not differ by the $\mathrm{F}$ test at $5 \%$ probability

Sá et al. (2014) produced yellow passion fruit seedlings (Passiflora edulis L.) and observed up to $17.40 \%$ more total dry mass of plants grown in containers with capacity of $2 \mathrm{dm}^{3}$ of substrate in relation to plants grown in $1 \mathrm{dm}^{3}$ containers, probably due to the restriction for root growth when using smaller volume containers and lower substrate volume, consequently with less nutrients available to plants.

Figure 1 shows the superiority of seedlings produced in substrates containing soil (T1 and T5) and substrate composed of soil + sand + bovine manure (T3 and $\mathrm{T7}$ ), in relation to substrate composed of soil + sand (T2 and T6) and commercial substrate (T4 and T8), especially when produced in larger volume container of $1.8 \mathrm{dm}^{3}$ (T5 to T8).

Greater growth of mangabeira seedlings occurs when soil or soil + sand + bovine manure substrate and the largest volume container are used. 
Figure 1. Mangabeira seedlings Hancornia speciosa Gomes produced on different substrates and container volumes.

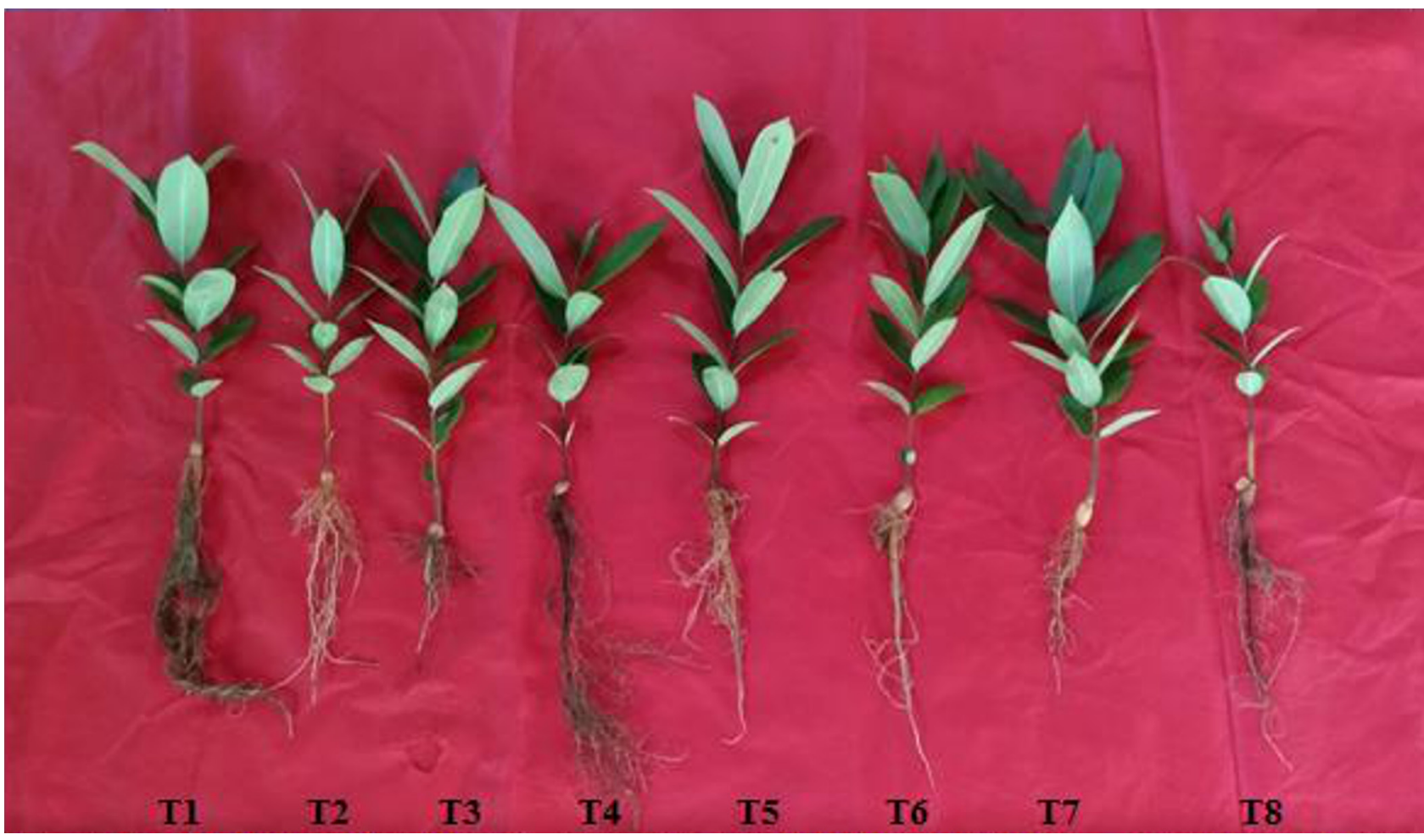

T1 - soil in $0.9 \mathrm{dm}^{3}$ container; T2- soil + sand in $0.9 \mathrm{dm}^{3}$ container; T3- soil + sand + bovine manure in $0.9 \mathrm{dm}^{3}$ container; T4- commercial substrate in $0.9 \mathrm{dm}^{3}$ container; T5 - soil in $1.8 \mathrm{dm}^{3}$ container; T6- soil + sand in $1.8 \mathrm{dm}^{3}$ container; T7- soil + sand + bovine manure in 1.8 $\mathrm{dm}^{3}$ container; $\mathrm{T} 8$ - commercial substrate in $1.8 \mathrm{dm}^{3}$ container.

\section{REFERENCES}

Arrua, L.C.; Costa, E.; Bardiviesso, E.M.; Nascimento, D.M.; Binott, F.F.S. Protected environments and substrates for mangabeira seedlings (Hancornia speciosa Gomez) production. Engenharia Agrícola, 2016, 36, 984-995.

Cargnelutti Filho, A.; Araujo, M.M.; Gasparin, E.; Avila, A.L. Dimensionamento amostral para avaliação de altura e diâmetro de mudas de Cabralea canjerana. Ciência Rural, 2012, 42, 1204-1211.

Climate-Data.Org. Clima: Nova Xavantina. Disponível em <https://pt.climate-data.org/location/43173>. Acesso em: 10 abr. 2018.

Costa, E.; Ferreira, A.F.A.; Silva, P.N.L.; Nardelli, E.M.V. Diferentes composições de substratos e ambientes protegidos na formação de mudas de pé-franco de tamarindeiro. Revista Brasileira de Fruticultura, 2012, 34, 1189-1198.

Costa, F.M.; Anjos, G.L.; Camilo, G.B.M.; Oliveira, U.C.; Souza, G.S.; Santos, A.R. Produção de mudas de maracujazeiro amarelo em diferentes composições de substrato e ambiente. Revista de Ciências Agrárias, 2018, 41, 138-146.

EMBRAPA-Empresa Brasileira de Pesquisa e Agropecuária. Manual de viveiro e produção de mudas: espécies arbóreas nativas do Cerrado. Brasília, 2016.

Marinho, D.G.; Alviano, D.S.; Matheus, M.E.; Alviano, C.S.; Fernandes, P.D. The látex obtained from Hancornia speciosa Gomes possesses anti-inflammator activity. Journal of Ethnopharmacology, 2011, 135, 530-537.

Melo, J.T.; Silva, J.A.; Torres, R.A.A.; Silveira, C.E.S.; Caldas, L.S. Coleta, propagação e desenvolvimento inicial de espécies do Cerrado. In: Sano, S.M.; Almeida, S.P. (Org.). Cerrado: ambiente e flora. Planaltina: Embrapa - CPCA, 1998. p.195-243.

Morais, T.L.; Costa, A.C.; Menezes, M.; Souza, M.E. Produção de mudas de mamoeiro em função de diferentes substratos. Cultivando o Saber, 2017, 10, 408- 420.

Morzelle, M.C.; Bachiega, P.; Souza, E.C.; Vilas Boas, E.V.B.; Lamounier, M.L. Caracterização química e física 
de frutos de curriola, gabiroba e murici provenientes do cerrado brasileiro. Revista Brasileira de Fruticultura, 2015, 37, 96-103.

Neves, C.S.V.J.; Medina, C.C.; Azevedo, M.C.B.; Higa, A.R.; Simon, A. Efeitos de substratos e recipientes utilizados na produção de mudas sobre a arquitetura do sistema radicular de árvores de acácia negra. Revista Árvore, 2005, 29, 897-905.

Nunes, V.V. Caracterização e conservação de sementes de mangaba (Hancornia speciosa Gomes). Dissertação (Mestrado em Agricultura e Biodiversidade) Universidade Federal de Sergipe, 2018. São Cristovão, 2018. 81 f. Oliveira, R.J.; Silva, J.E.C.; Chagas, D.B. Morphology of fruits and seeds and germinate and initial development analysis of Hancornia speciosa. Cerne, 2018, 24, 269-279.

Oliveira, L.C.;Costa, E.; Oliveira, A.D.; Jorge, M.H.A. Emergência do baruzeiro sob ambientes protegidos e substratos. Revista de Agricultura Neotropical, 2014, 1, 10-16.

Paiva Sobrinho, S.; Luz, P.B.; Silveira, T.L.S.; Ramos, D.T.; Neves, L.G.; Barelli, M. A.A. Substratos na produção de mudas de três espécies arbóreas do cerrado. Revista Brasileira Ciências Agrárias, 2010, 5, 238-243.

Pereira, A.C.; Pereira, A.B.; Moreira, C.C.; Botion, L.M.; Lemos; V.S.; Braga, F.C.; Cortes, S.F. Hancornia speciosa Gomes (Apocynaceae) as potential antidiabetic drug. Journal of Ethnopharmacology, 2015, $161,30-35$

Pereira, A.V.; Pereira, E.B.C.; Silva-Júnior, J.F.; Silva, D.B. Hancornia speciosa: Mangaba. In: Espécies Nativas da Flora Brasileira de Valor Econômico Atual ou Potencial: Plantas para o futuro - região Centro-Oeste. Brasília: MMA, 2016. 215 p.

Pinheiro, E.A.; Coimbra, R.R.; Silva, K.L.F.; Ferreira, W.M.Characterization and phenotypic variability in natural populations of mangabeira in the state of Tocantins, Brazil. Revista Caatinga, 2018, 31, 560 - 571.

Queiroz, J.A.; Melém Júnior, N.J. Efeito do tamanho do recipiente sobre o desenvolvimento de mudas de açaí (Euterpe olaracea Mart.). Revista Brasileira de Fruticultura, 2001, 21, 460-462.

Queiroz, J.A.L.; Blanchetti, A. Efeito do armazenamento sobre o poder germinativo de sementes de mangaba (Hancornia speciosa Gomes). EMBRAPA: Macapá, Comunicado Técnico 58, 2001, 4 p.

Rodrigues, E.T.; Leal, P.A.M.; Costa, E.; Paula, T.S.; Gomes V.A. Produção de mudas de tomateiro em diferentes substratos e recipientes em ambiente protegido. Horticultura Brasileira, 2010, 1, 483-488.

Sá, A.J.; Lédo, A.S.; Lédo, C.A.S. Conservação in vitro de mangabeira da região nordeste do Brasil. Revista Ciência Rural, 2011, 41, 57- 62.

Sá, F.V.S.; Bertino, A.M.P.; Ferreira, N.M.; Bertino, A.M.P.; Soares, L.S.; Mesquita, E.F. Formação de mudas de maracujazeiro amarelo com diferentes doses de esterco caprino e volumes do substrato. Magistra, 2014, 26, 482-492.

Samôr, O.J.M.; Carneiro, J.G.A.; Barroso, D.G.; Leles, P.S.S. Qualidade de mudas de angico e sesbânia, produzidas em diferentes recipientes e substratos. Revista Árvore, 2002, 26, 209-215.

Silva Junior, J. F.; Ledo, A.S. (Org). A cultura da mangaba. 1. ed. Aracaju: Embrapa Tabuleiros Costeiros, 2006. 253p.

Silva, G.C.; Braga F.C.; Lima, M.P.; Pesquero, J.L.; Lemos, V.S.; Cortes, S.F. Hancornia speciosa Gomes induces hypotensive effect through inhibition of ACE and increase on NO. Journal of Ethnopharmacology, 2011, 137, 709-711.

Soares, A. N. R.; Santana, J. G. S.; Melo, M. F. V.; Muniz, A. V. C. S. Germinação de Sementes de Mangaba Submetidas à Secagem. IV Seminário de Iniciação Científica e Pós-Graduação da Embrapa Tabuleiros Costeiros, 2014, 395-403.

Zaccheo, P.V.C.; Aguiar, R.S.; Stenzel, N.M.C.; Neves, C.S.V.J. Tamanho de recipientes e tempo de formação de mudas no desenvolvimento e produção de maracujazeiro-amarelo. Revista Brasileira de Fruticultura, 2013, 35, 603-607. 